\title{
Reclaiming Religion: Why Empire Cannot Be Sustained ${ }^{1}$
}

\author{
Alexander Sieber, Claremont School of Theology, USA
}

Abstract: The new orthodoxy of neoliberal thinking has led to a reduction in both freedom and prosperity for the multitude by thrusting forth the modern Empire. By using the phenomenological method, I conclude that this new type of Empire cannot be sustained, because it tries to occupy the same space as the human spirit. Instead of reaching fulfillment, Empire faces inevitable fragmentation. To illustrate my point, I utilize Heidegger's conception of art.

Keywords: Empire, Multitude, Heidegger, Framing, Art, Filtering

\section{Introduction}

The prevailing belief in neoliberal thinking, the new orthodoxy, is that unfettered free markets lead to a free and prosperous utopia. Ironically, since neoliberalism took the driver's seat in western politics during the 1980s it has driven mankind to a place of marked reduction in both freedom and prosperity; it has driven mankind to where the public is under the control of a military-economic-spiritual power complex led by, and for the primary benefit of, less than one percent of the population. Neoliberal thinking has driven modernity to empire. Staying on this course, can this type of empire succeed?

In this paper, I argue that Empire, as created by neoliberal groupthink, cannot succeed, because censorship goes on in the (so-called) Free World on an enormous scale. Using a Heideggerian critique of social analysis, I reason that art and communication are a natural reaction to censorship, so we should expect for today's idolatrous and censorship filled global empire to revert. The great paradox is then that the spiritually oppressive Empire (Polity) is at once Marx's epitome of religion and the destroyer of communication (society's art), an essential requirement of religion. This makes Empire truly oppressive to the human spirit. By considering Beyond the Spirit of Empire, Occupy Religion, Multitude and The Clash of Civilizations, this paper shows the extent to which Empire occupies religion. One can see the extent to which people can and will revolt to reclaim it-leading to Empire's inevitable fragmentation.

\section{The Status Quo}

What is happening in the contemporary world is the result of a worldwide empire greater than any before it. Then they said: "The sun never sets on the British Empire." Today they say: "The Street never sleeps." Wall Street influences the world on a scale much greater than any government. We saw how large cash flows can cripple nations in the East Asian contagion of 1997-1998. The crisis of 2008 sent most of the world economy into a spiral after several major Wall Street banks went broke. The capitalist dream died for many along with their savings and livelihood. How did this happen? How did the free world lose? America, with its pure past, dominant present, and providential future could never fail, right?

\section{What is Empire?}

Today, Empire is not a nation. Its symbol is not an army. Empire is:

\footnotetext{
1 Sieber, A. (2015). Reclaiming Religion: Why Empire Cannot Be Sustained. The International Journal of Civic, Political, and Community Studies, 14(1), 41-47.
} 
A particular formation of government and power and, given its pretense to be global, generates a "collective spirit," an anthropological construction, that allows and approves of certain behaviors, reactions, feelings, and attitudes of the social and political actors, that shapes a certain logic and way of conceiving life, and that imposes and translates itself into values and a hegemonic Weltanschauung. (Míguez, Rieger, and Sung 2012, 2)

Empire therefore operates as a "trinity" of economic power, military power, and "spirit" (Míguez, Rieger, and Sung 2012, 2). This essay highlights the human cost of Empire, because it is impossible to talk about the modern neoliberal utopia without talking about the human spirit. The human spirit has taken an enormous blow in the wake of a utopia whose proponents favor their model because of its guarantee of greater freedom and prosperity. To show this particular negative impact, I must introduce the philosophy of phenomenology. Phenomenology is an approach that, among other things, concentrates on the study of consciousness and the objects of direct experience. It allows the analyzer to look at people within and to look from the way in which it is lived and experienced. The phenomenological method of social theory has been applied primarily to anthropological fieldwork. In his book Tree Leaf Talk: A Heideggerian Anthropology, James F. Weiner translates the contribution of the German philosopher Martin Heidegger.

\section{Art}

In chapter seven, "The Community as a Work of Art," Weiner tells that artwork has a transcendent effect as a technique for exposing the limits of human relationality. Weiner says that social relations have the capacity to draw a perspective that is unworldly. They make the spiritual visible. Weiner writes:

Social relations, including the ones we are most likely to isolate as productive, reproductive, ritual, religious, and artistic, all have some capacity to draw forth some perspective on what we can call, for lack of a better term, this unworld. What we isolate as artistic procedures as such are perhaps the most perspicuous and forceful versions of such a drawing-forth. (Weiner 2001, 106)

In effect, art can be empowering. In religious practices and any other practices, using a mask empowers its wearer. Weiner argues that "the mask was the incarnate form of something altogether without qualities, namely Will to Power itself" (Weiner 2001, 110). The men of the Manambu tribe of Papua New Guinea believe that by using magic spells and wearing masks, they can reach transcendence. Masking is platonic, literal and theoretical. Its meaning may have prompted the use for the now famous Guy Fawkes Occupy mask.

Because of Empire, much of the human race is losing its essential Will to Power. Humans have a life force within them and between them, which is regulated via art or, alternatively, communication. As Weiner writes, artwork also has a transcendent effect as a technique for exposing "the limits of human relationality" (Weiner 2001, 105). Weiner introduces another Heideggerian term called framing. Framing is the bordering of a world. A world is the domain of the everyday. Everyday forms of understanding are formed in the world. Framing is the fracturing of one world into smaller ones. It separates people and ideas. Even fantastic things like theories can be trapped or tightly fixed to the everyday world. Tyranny of separation can become commonplace and can have far reaching implications. Is there evidence that communication really is needed to be human? Heidegger answers: 
Enframing means the gathering together of that setting-upon which sets upon man, i.e., challenges him forth, to reveal the real, in the mode of ordering, as standingreserve. Enframing means that way of revealing which holds sway in the essence of modern technology and which is itself nothing technological. (Heidegger 1977, 20)

According to Heidegger, framing and the human capacity to be human are at odds. He is not alone in these concerns. Self-determination theory, which sprung out of the 1970s, states that a human has three basic needs: competence, relatedness and autonomy.

Empire coldly frames workers into lives where communication is not possible. Empire tries to change men into machines and, for that, is a spiritually deficient system. Humans care, love, have emotion and bodies, risk, commit and live beyond conformity. These are all qualities that computers, according to Heideggerian philosopher Hubert Dreyfus, can never have. Artificial intelligence is what Empire aims to make humanity. The question remains: how can humans liberate themselves from framing to become more human? To answer this question one must look at why Empire seeks to frame in the first place.

Deliberate framing is an attempt to control the art (communication) or power of the individual. Empires frame because empires seek power. As stated earlier, Empire has a trinity of economic power, military power, and spirit. Military power will be exerted, economic power will be exerted, and spirit will be manipulated to grow the Empire. The agents of power are the people themselves. The controlling Empire can dictate policy using the soft power of spirit. So, why does Empire seek power? Empire seeks power because it seeks social order for its own proliferation as has been true of all previous empires as well. Controlling information is vital for the Empire to sustain and grow itself. The only problem for Empire is that framing in and of itself is a form of communication. It is then the task of Empire to be as subtle as possible in the use of soft power or coercion.

There is a silver lining though; the one major hope for civilization that is subjected to extreme framing (the process of censorship) is in itself communication. This means that Empire's soft power can backfire. In the long run, under an oppressive regime, social order cannot be maintained through mass framing. Framing can work as a counterbalance. Much like a weapon, framing can be used as a dangerous tool. But that does not mean that the user cannot be hurt too.

For to provide a new frame is at the same time to re-enframe the entire field within which things are isolated and placed in meaningful relations with other things. Any single pattern is not stable; what is stable is the human capacity to frame and reenframe. And this capacity demands that we consider concealment as fundamental to meaningful articulation and communication. (Weiner 2001,113)

This is the power of communication, and Empire knows it.

Heidegger believed that everyone wears a mask; he believed that every exterior change in action requires a change in mask or personae. Heidegger and Marx accepted that "the process of masking or concealment is fundamental to human conceptualization. All living things evince a movement, without which change and development would not be possible, and, as Marx noted, it is impossible to consider growth apart from change in form" (Weiner 2001,110 ). Warfare is one such creative act that can aid the suppression of mundane sociality. In his research on the Manambu, Simon Harrison writes, "Polity is perhaps most real at the climax of articulatory rituals, and it is a hard-won, rare and momentary achievement" (Harrison 1993, 193-4). In other words, Empire always wears a cunning mask and relies on its own hegemony to reach its utopia.

\section{The Spirit of Empire}


If a dominant state is the spirit of the society, then the Polity (Empire) must systematically control and destroy communication (society's art) so as to maintain social order. One can draw a new conception of spirit from Karl Marx. Marx loved religion, yet was very critical of the hegemonic role of religion. His greatest vision of the metaphysical was the State (Polity). He believed that man is estranged from his real, essential nature by making religion. Religion, according to Marx, is worldly and, therefore, secular. He believed that religion could deal with the tyranny of everyday life, yet is man-made. Marx thus believed that man is a non-individualistic, non-rational, free-less entity.

In his essay On the Jewish Question, Marx addresses the subject of religion and the State. "A state can be a free state without man himself being a free man" (Marx 1992, 218). He claims that the State is the theological entity. The more perfect the state is, the more religion there is. "It therefore follows that man liberates himself from a restriction through the medium of the state, in a political way, by transcending this restriction in an abstract and restricted manner, in a partial manner, in contradiction with himself" (Marx 1992, 218). Mass influence or restriction of communication is vital for imperial utopia. Restricting art, as I reasoned earlier, suffocates religious spirit. Polity is aberrational and tangible at the climax of articulatory rituals. This points us to the crux of this paper, which is that communication is the categorical war ground between two opposing religions: that of the Polity and that of the people. This puts Empire and the multitude at odds.

Empire only accepts entities after they submit to guidelines imposed by the Empire. The stated intention of Beyond the Spirit of Empire (by Néstor Míguez, Joerg Rieger, and Jung Mo Sung) is "to clarify what constitutes this opposition, and to discern what this spirit of empire is and what can arise as an alternative and an expectation, a different way of conceiving power and human life" (Míguez, Rieger, and Sung 2009, 2). It describes Empire as an entity that wishes to have "the entire world... conform itself to a single mode of operating in the economy, or conceiving politics, of managing power, and to a supreme military power" (Míguez, Rieger, and Sung 2009, 10). Empire engages in what I call filtering, a hegemonic discrimination process. In the words of the authors, "everything must adapt" to a "framework" (Míguez, Rieger, and Sung 2009, 10). How is this enforced? The powerful Empire can engage in what is called labeling. Labeling allows Empire to exile potential dissonance out of the political arena. One such example is the use of rhetoric or jargon like "terrorist." This makes the public disillusioned and latent. The citizen's power then becomes inert, because politics and expression are no longer empowering. As a result the West is post-democracy. This has left many shut out and shut up.

Empire largely controls media. Media are powerful tools that are used to feed the interests of the Empire, which includes business and military interests. Through coercion of the public media Empire creates "the sensation that the desires established by the market are the only valid ones, the only possible ones, the only path that leads us to that fullness enjoyed by imperial subjects" (Míguez, Rieger, and Sung 2009,18). The result is the loss of agency of the public because of media coercion. Coercion is the equivalent to propaganda. Looking back at the Soviet Union, would it have lasted without censorship? If Mikhail Gorbachev had not allowed glasnost would the thinking of Yegor Gaidar and free markets have ever corrupted the Soviet state? The Soviet Union by the 1980's was a failed utopia partly because it had exacerbated its capabilities (because it had made imperial priorities, like military expenditure, corruption, etc.) at the expense of the Soviet people. In the fog of the Cold War, free thinking brought things into clarity. Gorbachev knew that radical framing was crippling Soviet Russia and the only way out. Soviet Russia is just one example. What this paper has been leading up until now is the evidence for my Heideggerian analysis.

Just like the Polity gaining power and becoming the religion, Empire becomes the center of ritual and way of life. The authors of Beyond the Spirit of Empire go into detail on how consumerism creates ritual and a way of life based on the Empire's values. 
Romanticism and repression become the mechanisms of hegemony. The authors call this "a sense of power and control that is hard to achieve anywhere else in real life and resembles the sort of omnipotent power that borders on classical theist images of the divine" (Míguez, Rieger, and Sung 2009, 43). The new high priests are the elite capitalists and their god is hegemonic Empire. The spirit of Empire is clearly coercive and contrary to religious virtue. The tenets of Empire are those of neoliberalism: privatization, corporations freed from any obligations, and social spending reductions. Elites believe, in their own groupthink, that these standards would lead to greater prosperity, and political, religious and cultural freedom. But, there is hope.

\section{Examples of Fragmentation}

As argued above, people tend to fight back against intense suppression. With subjectivity, citizens can regain agency. A subjective person is by nature free. That includes the quality of possessing perspectives, experiences, feelings, beliefs, desires, and/or power. "True subjectivity and agency is formed in situations of pressure, first as lack and fragmentation but then shaping up as counter-pressures that respond to the repressions of life" (Míguez, Rieger, and Sung 2009, 161). The response to the suppression of the 99 percent or, multitude, was the Occupy movement and is illustrated in Occupy Religion: Theology of the Multitude and Multitude: War and Democracy in the Age of Empire.

In Occupy Religion the authors examine the religious significance of the Occupy movement. The protesters were determined to bring the people or multitude together, partly, to fight to regain the religious spirit that had been inhabited by Empire. Whether they knew it or not, they were involved in ideological warfare. Organizers combated imperial hegemony by using advanced communication. Everyone in the Occupy movement considered himself or herself a leader. Rather than leaderless, these people all contributed to the collective cause. Under this format, the Occupy movement set up a Free School University to:

Provide education for the protesters and members of the community and hosted a Howard Zinn Memorial Lecture Series featuring radical thinkers such as Noam Chomsky, who has critiqued American imperialism. International progressive academic and public figures such as Judith Butler, Angela Davis, Naomi Klein, Gayatri Chakravorty Spivak, Cornel West, and Slavoj Žižek. (Rieger and Pui-lan 2012, 36)

Protesters used YouTube to broadcast speeches, posted on the web, used Twitter and collected print media for wide circulation. They had a unifying goal to "form decentralized and horizontal networks of self-governing institutions from below and to hold those who have state power accountable" (Rieger and Pui-lan 2012, 40). Not only that, they wanted to occupy the spiritual sphere. The authors believe that "by sharing power horizontally, the Occupy movement releases the potential of people to claim their agency" (Rieger and Puilan 2012, 40). The postulate of Beyond the Spirit of Empire regarding "grace under pressure" is elaborated on in Occupy Religion where it is called "theological surplus" in the midst of struggle (Rieger and Pui-lan 2012, 62). Rieger and Pui-lan are referring to the reflex of those whose human spirit has been suffocated by the Polity.

What Occupy protestors realized was that spirit works for agency. This means that agency is gained through the religious spirit and not through the spirit of Empire. Furthermore, the Occupy movement was about seeing the interconnectedness of community. The protesters saw past the 1 percent barricade. They, as they said, represented the 99 percent; they sought justice. There was a true appreciation of otherness in occupy protests, too. It was as if these diverse communities were not connecting but re- 
connecting. Occupy was about reassembling a true community with real relationships. Worship, as the authors note, "has nothing to do with passive reception or narrow religious ritual. Worship, as the prophet Isaiah points out, has to do with the production of justice" (Rieger and Pui-lan 2012, 77). Further, they argue that "love is realized through agency and production, which constructs and reconstructs self and other and their relationship with the community; it has nothing to do with being starry-eyed or mesmerized by another person" (Rieger and Pui-lan 2012, 80). Subjectivity, power, and reclaiming agency is where the war over communication is taking place. Occupy Religion is a manifesto that testifies to this.

Not bound by any rigid traditions, the multitude created new and innovative ways to create worlds and connections. Second Life, a virtual world where a webcast religious service was provided for protesters, is an example of the revolt against hegemony. This broke frames that the imperial world had created. Virtually everyone could access the virtual space because it was a simple church service. It may not have been free, as there was an opportunity cost that went with creating an avatar for the broadcast, but those with access certainly put a dent into the machine (Reyna 2002, 103). Any free communication and creation of sacred space is a move in the right direction to regain subjectivity among the multitude.

There are various ways that hegemonic framing goes on in Empire. A quote from Rev. Martin Luther King, Jr. encapsulates the Heideggerian concept and dynamics of framing. King says, "All life is interrelated. We are caught in an inescapable network of mutuality, tied into a single garment of destiny" (Rieger and Pui-lan 2012, 130). Multitude elaborates on the issues of framing. "Depravation, in other words, may breed anger, indignation, and antagonism, but revolt arises only on the basis of wealth, that is, a surplus of intelligence, experience, knowledges, and desire" (Hardt and Negri 2004, 212). To put Hardt and Negri in other words: every revolution requires weaponry. Multitude also has some examples that go beyond the Occupy movement; Hardt and Negri's book mentions the technology seen in Occupy but puts it into a broader context called biopolitics. Biopolitics, according to Hardt and Negri, is typically anti-capitalist rebellion using life and the body as weapons.

The Zapatistas story is a great example of biopower utilization. They have organized superbly using the tools of modernity in 1994. As a horizontally linked structure that is difficult to detect and highly organized, the Zapatistas succeeded to revolt and create communities in southern Mexico against what they saw as Empire. The Zapatistas are a great example of people who committed to change. In the creative art form of warfare, the Zapatista National Liberation Army put on the mask of secrecy, a veil if you will. They reframed communities to allow for communication. Biopolitics empowered them. Because of advanced technological organization (networking), the communities were not oppressed by the conforming nature of imperial capitalism. Human relationality itself becomes a victim under modern globalization. As stated before, the spirit of Empire has entered this sphere and suffocated what it means to be human, that is, having the agency to live beyond conformity.

Neoliberal politics infringe on the human spirit, because through loss of representation comes a lack of subjectivity and agency. Multitude also offers a summary of Samuel Huntington's view of globalization and Empire. Huntington believes that democracy should be "tempered with authority, and various segments of the population must be kept from participating too actively in political life or demanding too much from the state" (Hardt and Negri 2004, 33). Clearly, Huntington is in line with the neoliberal thinking behind top-down government that is interested in coercion and loss of representation. This is very different from the bottom-up, leaderless paradigms that were proposed by the authors of Beyond the Spirit of Empire, Occupy Religion and Multitude. In his analysis, Huntington writes, 
It is human to hate. For self-definition and motivation people need enemies: competitors in business, rivals in achievement, opponents in politics. They naturally distrust and see as threats those who are different and have the capability to harm them. The resolution of one conflict and the disappearance of one enemy generate personal, social, and political forces that give rise to new ones. "The us versus them tendency is," as Ali Mazrui said, "in the political arena, almost universal." In the contemporary world the them is more and more likely to be people from a different civilization. (Huntington 1996,130)

Huntington's politics are detrimental to the multitude. Eventually, like the Occupy movement people will put on their masks, become suprahuman, take a risk, and revolt.

\section{Conclusions}

The new orthodoxy of neoliberal thinking has led to a reduction in both freedom and prosperity for the multitude. By using the phenomenological method I conclude that this type of Empire cannot succeed because it tries to occupy the same space as the human spirit. It is only natural therefore to be a backlash to the repressive nature of Empire after it enters the spiritual field. Empire has dehumanized its subjects and for that reason cannot succeed. The human spirit cannot be suppressed eternally for Empire to last forever. We have seen dehumanization and colonialization go through a reversal process before, and it will happen again. My explanation is that we live in a self-correcting and ever-changing world of framing and re-framing guided by the tension between the state and the people, a world Heidegger equated with waxing and waning. As we know, a full moon only lasts for a short moment, and so must the sun set on the Empire. Each revolt is an answer to the suppression of human expression. As Heidegger said, humans are being-towards-death and therefore must make a decisive sacrifice for their own future. Revolt is that moment. I reiterate, in the end, biopolitics and alternative organization can level the playing field in the war of communication. Although mankind may be living under Empire, technologies exist (that enable the spread of art) which can counteract the forces of imperialism that neo-colonialists support.

\section{REFERENCES}

Hardt, Michael, and Antonio Negri. 2004. Multitude: War and Democracy in the Age of Empire. New York: Penguin.

Harrison, Simon. 1993. The Mask of War. Manchester: University of Manchester Press.

Heidegger, Martin. 1977. The Question Concerning Technology, and Other Essays. New York: Harper \& Row.

Huntington, Samuel P. 1996. The Clash of Civilizations and the Remaking of World Order. New York: Simon \& Schuster.

Marx, Karl, Lucio Colletti, Rodney Livingstone, and Gregor Benton. 1992. Early Writings. Harmondsworth, Eng.: Penguin in Association with New Left Review.

Míguez, Néstor, Joerg Rieger, and Jung Mo Sung. 2009. Beyond the Spirit of Empire. London: SCM.

Reyna, Stephen P. 2002. Connections: Brain, Mind, and Culture in a Social Anthropology. London: Routledge.

Rieger, Joerg, and Kwok Pui-lan. 2012. Occupy Religion: Theology of the Multitude. Lanham: Rowman \& Littlefield. 
Weiner, James F. 2001. Tree Leaf Talk: A Heideggerian Anthropology. New York: Berg.

\section{ABOUT THE AUTHOR}

Alexander Sieber: Master's Student, Religion, Ethics and Society, Claremont School of Theology, Claremont, California, USA 